\title{
CHRISTMAS IN THE Missions OF NORTHERN NEW SPAIN
}

\section{I}

n 1982, native historian Joe Sando vividly described the Christmas season at Jémez Pueblo in northern New Mexico. Throughout the pueblo, figures of the Christ Child lay on display in homes in prominent, specially-decorated areas representing the stable in Bethlehem. During his childhood, Sando remembered that Hemish families roasted corn in their fireplaces, while elders drew pictures of wild game animals and birds, as well as important crops, on the wall next to the fireplace, in hopes that the birth of Christ would also result in the birth of the animals and plants drawn on the wall. In Jémez today, although the roasting of corn and drawings on the fireplace walls have been replaced by the exchange of gifts and watching television, some seasonal customs continue. Pine logs for communal bonfires rest neatly in square piles in front of each home. Christmas Eve bonfires attract the newborn Infant Jesus, and children gleefully play and dance around them. When the fires die out, the Hemish return to their homes to await midnight mass. After mass at the church, worshipers follow the newborn Infant in procession through the community. The next morning, as the first rays of daylight become visible in the east, animal dancers appear on the hilly skyline to the east and southwest. By the time the sun leaves the eastern horizon, the animals have arrived in the village, gathering in front of the drummers, who sing welcoming songs. The people arrive to welcome the animals, who process to the plaza, where they dance all day. ${ }^{1}$

Sando's vibrant description of a unique, blended Christmas celebration prompts the question of how such celebrations, both today and over the last four hundred years, fused together indigenous understandings and practices, Hispanic folk traditions, and Catholic liturgy and belief. Over the centuries of contact and exchange between Indians and Europeans in New Spain's northern borderlands, the characteristics of communal celebrations for special occasions have shifted, reflecting centuries of negotiations over culture, sacred space and time, and religious belief. Hemish Christmas rituals reveal multiple cultural influences. Native

1. Joe S. Sando, Nee Hemish: A History of Jémez Pueblo (Albuquerque: University of New Mexico Press, 1982), pp. $218-219$. 
dances, plants, and animals are incorporated in indigenous time and space-a bonfire at night and gathering at sunrise, likely influenced by traditional practices of the Hemish and those of other Puebloan groups. Catholic doctrine and liturgy structure processions and mass on the Catholic-timed feasts of Christmas Eve and Christmas Day, and American popular culture adds television and gift giving. More subtle elements of cultural mixing are also present in the racial and cultural self-identities of dancers, observers, processors, communicants, and family members, who might even describe their Christmas celebrations as "traditional." 2 The results of cultural and religious encounters between Indians and Spaniards were fashioned most intensely in the Franciscan and Jesuit missions of the seventeenth and eighteenth centuries.

What were the elements of Christmas celebrations in New Spain's northern mission communities? How did they incorporate and interpret elements of Catholic, European and indigenous practices and beliefs? Undertaking a study of mission life, including Christmas celebrations, presents many challenges. In New Spain's north, indigenous peoples left no written accounts of their interaction with Franciscan and Jesuit missionaries. In some areas, native groups adapted and have survived to the present, and their oral tradition and cultural practices provide valuable evidence with which to interpret Spanish sources. Other Indians did not survive as distinct ethnic groups due to the pressures of disease, ecological change, and colonization. ${ }^{3}$ Examining written accounts of the rituals and ceremonies associated with religious feast days can provide glimpses of the results of the extended intercultural contact in frontier mission zones. But these accounts are incomplete and written from specific cultural understandings and power relationships. Employing theoretical constructs, such as syncretism or cultural hybridity to explain the cultural artifacts of mission life can be problematic, too. ${ }^{4}$ Indigenous mission communities were

2. Many excellent studies have explored racial identification and ethnicity in the borderlands and Latin America in the colonial and national periods, including Matthew Restall, ed. Beyond Black and Red: African-Native Relations in Colonial Latin America (Albuquerque: University of New Mexico Press, 2005), Steve J. Stern, Peru's Indian Peoples and the Challenge of Spanish Conquest: Husamanga to 1640 (Madison: University of Wisconsin Press, 1982), David Gutiérrez, Walls and Mirrors: Mexican Americans, Mexican Immigrants, and the Politics of Etbnicity (Berkeley: University of California Press, 1995), Martha Menchaca, Recovering History: Constructing Race: The Indian, Black, and White Roots of Mexican Americans (Austin: University of Texas Press, 2001).

3. Edward Spicer identified groups that survived beyond the colonial period as "cultural enclaves" and "enduring peoples." Cycles of Conquest: The Impact of Spain, Mexico, and the United States on the Indians of the Southwest, 1533-1960 (Tucson: University of Arizona Press, 1962). For more recent discussions of the factors that contributed to these cultural changes in northern New Spain, see Cynthia Radding, Wandering Peoples: Colonialism, Ethnic Spaces, and Ecological Frontiers in Northwestern Mexico, 1700-1850 (Durham: Duke University Press, 1997), and Susan M. Deeds, Defiance and Deference in Mexico's Colonial North: Indians under Spanish Rule in Nueva Vizcaya (Austin: University of Texas Press, 2003).

4. Some of the problem is related to the "loaded" nature of each term. Both syncretism and hybridity may be identified by participants in and observers of ritual and material culture. I understand syncretism broadly as the combination of different beliefs, practices, or forms that occurs when multiple cultural groups interact. On syncretism, see Jeanette Favrot Peterson, The Paradise Garden Murals of Malinalco, introduction, and Sidney M. Greenfield and André Droogers, cds., Reinventing Relgions: Syncretism and Transformation in Africa and the Americas (Lanham, MD: 
entangled in webs of power that involved Spaniards, missionaries, relocated Indian converts, neophytes from different ethnic groups, and nonmissionized groups. They responded to the missionary programs of religious indoctrination and Hispanicization that ranged from outright revolt to accommodation. Syncretic, or blended, cultural celebrations resulted from the juxtaposition of Spanish and native ritual calendars and ceremonial practices. Missionary reports, letters, and visitors' accounts of life in the missions, including descriptions of Christmas festivities, illustrate the adaptation of Christian liturgy and European folk traditions to the practical realities and local practices of life in frontier mission communities.

Blending of cultural practices in shared ritual celebrations was certainly not limited to Christmas, and began long before European missionaries arrived with the goal of converting and civilizing the large indigenous population of the Americas. ${ }^{5}$ Indigenous groups borrowed ball games, pole dances, and songs from each other in much the same way that folk dances, plays, and melodies spread throughout the European continent. ${ }^{6}$ When Franciscan and Jesuit missionaries and Spanish settlers moved north from central New Spain, their years were punctuated by the proscribed celebrations of the Christian calendar-particularly Christmas, Holy Week and Easter, Corpus Christi, and the feast days of the saints. In contrast, Indians of the north marked their time by natural cycles of the sun, moon, and agricultural rhythms of planting and harvesting. These differing ritual calendars coincided on holidays such as Christmas, which fell at the winter solstice.?

While the season of Christmas in Europe and the United States has received scholarly attention, much of the research focuses on the nineteenth century and the development of a consumer culture surrounding the holiday. ${ }^{8}$ Descriptions of Christmas traditions in Latin America have been written for popular audiences, ${ }^{9}$ and musicologists and folklorists have written about the classical repertoire of villancicos

Rowan and Littlefield, 2001). Hybridity, a term which acknowledges the "mixed descendancy of objects and practices," can be problematic because it assumes one European, or colonial practice or set of beliefs, in opposition a monolithic non-European practice or set of beliefs. Sec Carolyn Dean and Dana Leibsohn, "Hybridity and Its Discontents: Considering Visual Culture in Colonial Spanish America," Colonial Latin American Reviow 12:1 (2003), pp. 5-35. As Dean and Leibsohn point out, twenty-first-century observers often find hybridity (or syncretism) in descriptions that historical actors did not identify as remarkable.

5. Litcrature on the effects of cross-cultural contact on music, dance, art, and ritual is extensive and generally employs models such as syncretism or hybridity in order to explain the processes and outcomes of interaction.

6. See, for example, Jane C. Desmond, "Embodying Difference: Issues in Dance and Cultural Studies," Cultural Critique 26 (Winter 1993-1994), pp. 33-63.

7. Christmas was celebrated by the 4th century, and coincided with the winter solstice-December 25 on the Julian calendar. The late Roman Empire's heliocentric religion also included a festival for the return of the Sol invictus. S. K. Roll, "Christmas," New Catholic Encyclopedia, volume III (Detroit: Thomson/Gale, 2003), pp. 551-557.

8. Stephen Nissenbaum, The Battle for Christmas (New York: Alfred A. Knopf, 1996); Bruce David Forbes, Christmas: A Candid History. (Berkelcy: University of California Press, 2007).

9. Charito Calvachi Wakefield, Natividad Latinoamericano, 2nd rev. ed. (Lancaster, Penn: Latin American Creations Publications, 1999). 
and liturgical drama, ${ }^{10}$ but celebrations and customs have not received the extensive analytical treatment of those in the United States. Still, excellent studies of the role of ritual and cultural celebrations in articulating and shaping identity and fashioning power relations in colonial Mexico demonstrate that insights about the processes and products of cultural exchange can be gained by investigating the rituals, such as those for Christmas, of the mission communities of Northern New Spain. ${ }^{11}$

\section{European Christmas Celebrations}

From the Middle Ages, Christians have celebrated the birth of Jesus with both liturgical and extra-liturgical activities. The penitential period of Advent led to Christmas Eve, a day for fasting and contemplation, which generally ended with evening sung Vespers. On Christmas Day, three masses, one shortly after midnight, one at dawn, and one in the afternoon, were conducted in cathedrals, each with their own readings and songs. ${ }^{12}$ By the fourteenth century, these masses included religious dramas. Additions to the liturgy became common in the Middle Ages as a way of explaining doctrine to illiterate congregation members. Tropes, or musical additions to chant, began as brief texts for responsive recitation. They also included words and melody added to the liturgy to accentuate important concepts, and their use dramatically expanded, into solos, choir performances, or even liturgical drama by the thirteenth century. ${ }^{13}$ Sequences, which were added after the Gradual, elaborated on the Gradual's text with prose or verse, usually set to music. ${ }^{14}$ Both tropes and sequences allowed for musical composition and creativity beyond the confines of the structured liturgy, and they were popular amongst all classes of individuals. The goal of such additions was to involve all observers not only as passive witnesses, but as active participants in the adoration of Christ. ${ }^{15}$

10. For example, Robert Stevenson, "Mexico City Cathedral Music: 1600-1750," The Americas 21:2 (Oct. 1964), pp. $111-135$ and Christmas Music from Baroque Mexico (Berkeley: University of California Press, 1974), pp. 111-135, and Carlos Miró-Cortez, "The Nativity in Iquique, Chile. The Christmas Carols of the Fraternities of Las Cuyacas and Pastoras" Studia Musicologica Academiae Scientiarum Hungaricae 18 (1976), pp. 81-152.

11. Linda A. Curcio, "Saints, Sovereignty and Spectacle in Colonial Mexico," Ph.D. dissertation, Tulane University, 1993; Linda Curcio-Nagy, "Giants and Gypsies: Corpus Christi in Colonial Mexico City," Rituals of Rule, Rituals of Resistance, ed. William Beezley, Cheryl English Martin, and William French (Wilmington, N. Carolina: SR Books, 1994); Frances L. Ramos, "Succession and Death: Royal Ceremonies in Colonial Puebla," The Americas 60:2 (2003), pp. 185-215.

12. For an overview of the medieval Christmas liturgy, see R. F. Buxton, "Christmas," Newp Westminster Dictionary of Liturgy and Worship, J. G. Davies, ed. (Philadelphia: Westminster Press, 1986), p. 171. See also Augustine Thompson, Cities of God: The Religion of the Italian Communes, 1125-1325 (University Park, Penn: Pennsylvania State University Press, 2005), pp. 275-277.

13. The musical definition of trope is an addition or embellishment of the text of the Mass or Divine Office. See William L. Smolden, The Music of the Medieval Church Dramas (London: Oxford University Press, 1980), and Fernando Lázaro Carreter, Teatro Medieval (Valencia: Castalia, 1958).

14. The gradual (Latin graduale) is an antiphon performed after the epistle, part of the Proper of the Mass. Sequences were embellishments of or additions to the Gradual.

15. Smolden, pp. $215,229$. 
Costumes, stringed instruments, minstrels, and dancing entered the courtyards, naves, and sanctuaries of churches, blurring the boundaries between sacred liturgy and profane folk culture.

In medieval Europe, the Franciscan Order extended Catholicism to a wide population in town and countryside through the use of religious plays containing music. St. Francis is credited with the first organized recreation of Christ's nativity in Bethlehem, in a cave above Greccio, Italy. Men and women of the town processed up the hillside carrying torches and raising their voices in song. A group of townspeople and animals created a tableau of the holy family before a manger inside the cave. Then, according to his biographer and companion, Thomas of Celano, Francis

sang the holy gospel in a sonorous voice. And his voice was a strong voice, a sweet voice, a clear voice, a sonorous voice, inviting all to the highest rewards. Then he preached to the people standing about and he spoke charming words concerning the nativity of the poor King, and the little town of Bethlehem. ${ }^{16}$

It is not surprising, then, that Franciscans showed special devotion in their celebration of Christmas, by organizing dramas that recreated the nativity story in schools and convents throughout Europe. By the sixteenth century, cathedrals and churches attached to the convents of the religious orders in Italian, Spanish, and French cities also hosted elaborate celebrations for Christmas and other first-class feast days, which spilled into the streets and continued into the evenings. Celebrations centered around the liturgy, but also included dramas and comedies. These plays depicted familiar and important stories, such as the angels' appearance to the shepherds announcing Christ's birth, the story of Adam and Eve and the tree of life, and the adoration of the Magi. Outside of the church, vendors provided food and material goods, minstrels performed, and the community engaged in dancing, singing, and revelry. ${ }^{17}$ The characteristics of popular musical practice-singing in the vernacular, using folk melodies, and worshiping beyond the confines of the church building-facilitated the participation and comprehension of a larger number of believers in worship. Shared repertoires and performances bound groups together and reinforced corporate devotion and identity. ${ }^{18}$ Church authorities were anxious to incorporate appropriate popular religious observances into official practice to spread the political and spiritual power of the Church, as well as to gain some control over the participants and elements of celebrations. In six-

16. Thomas of Celano, St. Francis of Assisi: First and second life of St. Francis, with selections from Treatise on the miracles of Blessed Francis, ed. and trans. Placid Hermann (Chicago: Franciscan Herald Press, 1963), pp. 42-44.

17. Richard H. Hoppin, Medieval Music (London: W.W. Norton, 1978), pp. 52-53, 172. Many of thesc practices continued into the fifteenth and sixteenth centuries. See Gustave Reese, Music in the Renaissance, rev, ed. (New York: W.W. Norton and Company, 1959), p. 491.

18. Kristin Dutcher Mann, The Power of Song and Dance in the Mission Communities of Northern New Spain (Berkeley: Academy of American Franciscan History, forthcoming), p. 59. 
teenth-century Seville, for example, the canons of the Church decreed that processions around the Church, when accompanied with music, augmented the devotion of city residents and encouraged them to follow and participate in the Divine Offices. ${ }^{19}$ Villancicos, popular songs with easily memorized refrains, were important components of processions and Matins, particularly on special occasions such as Christmas and Epiphany, in Renaissance Spain. ${ }^{20}$ Lyrics of lauda, or simple religious songs, and villancicos consisted of verses and refrains, with each song emphasizing Christian ideas and images-praising one God, following the examples of the lives of Mary and the saints, the virgin birth of Christ, and the sacraments. ${ }^{21}$

While these elements of popular religious culture reached out to large audiences, Catholic leaders faced the tension between attracting and retaining followers, while maintaining the purity of worship within the liturgy, especially under attack from Reformation leaders. ${ }^{22}$ In a limited fashion, Catholic leaders at the Council of Trent addressed concerns over the suitability of music, dances, and dramas that were part of celebrations for feast days. They set boundaries within which music and dance could operate, but local bishops were given flexibility to address local needs of religious expression through their control over religious celebrations. ${ }^{23}$ As a result, the tension between the proscribed liturgy for Christmas and other feast days, and folk practices surrounding these occasions, did not diminish. When Franciscans, Jesuits, and Spanish settlers moved to central and northern New Spain, they recreated both liturgical and extra-liturgical elements of these celebrations in new settings.

\section{Christmas in Sixteenth-Century Central New Spain}

From the start of the evangelization effort in the Spain's American colonies, regular clergy used the arts to teach Christian doctrine to potential converts. Indige-

19. Lourdes Turrent, La conquista musical de Mexico (México: Fondo de Cultura Económica, 1996), p. 40.

20. During Matins, villancicos sometimes replaced Latin responsories, and their spread from Spain throughout Europe and the Spanish empire made them one of the most significant types of music, both sacred and secular, in the seventeenth and eighteenth centuries. See Paul R. Laird, Towards a History of the Spanish Villancico (Warren, Michigan: Harmonie Park Press, 1997), p. 51, Tess Knighton and Alvaro Torrente, Devotional Music in the Iberian World, 14501800: The Villancico and Related Genres (Farnham: Ashgate Publishing, 2007), and Isabel Pope and Paul R. Laird, "Villancico," New Grove Dictionary of Music and Musicians, ed. Stanley Sadie, vol. 26 (London: Macmillan, 2001), pp. $621 \cdot 628$.

21. Franciscans and Domicans used laudi spirituali, or lauda, to teach doctrine. They were popular in European confraternities and in urban areas. See John Caldwell, "Lauda," New Grove Dictionary of Music and Musicians, ed. Stanley Sadie, vol. 14 (London: Macmillan, 2001), p. 367.

22. Martin Luther, John Calvin, and others did not reject the use of music for worship, but they found fault with dramas and comedies, as well as tropes and sequences. They also advocated that music used during worship should be sung in local languages, not in Latin.

23. Craig A. Monson, "The Council of Trent Revisited," Journal of the American Musicological Society 55:1 (Spring 2002), p. 10. Sec also H. J. Schroeder, Canons and Decrees of the Council of Trent (St. Louis: B. Herder Book Col, 1950), p. 151 . 
nous cultures in the Americas relied heavily on oral, physical, and visual representations of history. Liturgical drama, paintings, pantomimes, murals, and songs, made mass and doctrinal lessons more comprehensible and better piqued the curiosity of students. ${ }^{24}$ One of the earliest Franciscans in central Mexico, lay brother fray Pedro de Gante, encouraged the spread of Catholic rituals among the Indians by drawing on their talents in painting and dance and by layering Christian meanings and words on top of Nahua songs and dances. After organizing disappointing efforts to draw crowds to worship on feast days, fray Pedro began to understand that for the Nahua, adoration of the gods was accomplished through singing and dancing. To capture the idea of worshiping, while emphasizing Christian concepts, he composed a flamboyant song for Christmas with lyrics praising Christ's virgin birth and life according to God's law. Movement and dance conveyed the Christmas narrative. Students at the Convento de San Francisco learned the music, rehearsed the dance, and performed it in costume for the celebration of the Nativity of Christ. Unlike routine liturgy, this pageant attracted a large crowd:

So many came that the patio, although very large, could not hold them. Each province had set up its own stalls to entertain its leaders, and even ill persons came from a distance of seven and eight leagues, carried on hammocks, and others came almost equal distances by water, to hear the singing. ${ }^{25}$

Fray Pedro was the first of many missionaries in New Spain to encourage dancing and singing of Christian hymns on special occasions, such as Holy Week, saints' feast days, Christmas, and Corpus Christi. ${ }^{26}$ His account of this Christmas celebration, written many years later to describe his successful missionary techniques, pinpointed this Christmas celebration as one of the turning points in drawing crowds to worship.

Franciscans not only used familiar forms of worship, but also well-known images and concepts to explain Christian doctrine. Sermons and catechisms equating Christ and his birth with the coming of the sun, a concept which dated to Roman times in Europe, also resonated in Nahua culture. This solar-themed rhetoric was

24. See Louise Burkhart, "Pious Performances: Christian Pageantry and Native Identity in Early Colonial Mexico," in Native Traditions in the Postconquest World, Elizabeth Boone Hill, ed. (Washington, D.C.: Dumbarton Oaks, 1988), as well as Holy Wednesday: A Nabua Drama from Early Colonial Mexico (Philadelphia: University of Pennsylvania Press, 1996) and Othón Arróniz, Teatro de cpangelización (México: Universidad Nacional Autónoma de México, 1979) concerning drama. For the visual arts and evangelization, see Jeannette Peterson, The Paradise Garden Murals of Malinalco: Utopia and Empire in Sixteenth-Century Mexico (Austin: University of Texas Press, 1993) and Serge Gruzinski, Painting the Conquest: The Mexican Indians and the European Renaissance, trans. Deke Dusinberre (Paris: Flammarion, 1992).

25. Fray Pedro to the king, $6 / 23 / 1557$, in Alberto María Carreño, "Una desconocida carta de fray Pedro de Gante," Memorias de la Academia Mexicana de la Historia XX:1 (Jan-March 1961), pp. 16-20.

26. Charles Verlinden, "Fray Pedro de Gante y su época," Revista de historia de América 101 (Jan-June 1986), p. 117. 
used to convey the meaning and stress the importance of Christmas. ${ }^{27}$ Special festivities for Christmas-extra worship services, sermons, dancing, fireworks, and drama-attracted and involved entire communities, not only boys educated at Franciscan schools. Fray Toribio de Benavente (Motolinía) praised the methods of missionaries-teaching through the arts, emphasizing holidays, and capitalizing on familiar concepts-in his widely read 1541 history of the Indians of New Spain. These methods, particularly the use of music and art to convey Christian concepts and entice worshipers, were duplicated by Franciscans and Jesuits throughout the Spanish and Portuguese empires. ${ }^{28}$

In New Spain, as elsewhere, the Catholic ceremonial year was structured by a series of liturgical seasons (Advent, Christmas, Epiphany, Lent, Easter, and Pentecost), and punctuated by the celebration of specific feast days within these seasons. Christian feast days honored specific events in the life of Jesus Christ or the Church, and commemorated contributions of the saints. The imposition of religious festivals in colonial situations was an effective means of weakening indigenous religious bonds, or at least integrating Christian devotions into indigenous understandings. The aim of this type of restructuring of rituals and ceremonial time was to force new converts to act according to new markers of time, set by the Church, and to dissolve loyalty to old autochthonous markers of time. In central New Spain, festivities for Advent and Christmas were layered on top of a Nahua celebration dedicated to Huitzilopochtli. Panquetzaliztli, "raising of banners," was the fifteenth month of the Aztec ceremonial calendar, and it included a preliminary period of fasting, followed by the adornment and procession of an amaranth-dough image of Huitzilopochtli. ${ }^{29}$ At the conclusion of the image's procession around the city, it was raised to the temple and surrounded with smaller edible images of the god and of bones. A feast, which included consumption of the images, followed. ${ }^{30}$ The fast-

27. On the relation between Christ and the sun in the early church, see Philip Schaff, History of the Christian Church, 3rd ed., vol. III, ch. 77 (Peabody, Mass: Hendrickson Press, 1996). On representations of Christ as the Sun in sixteenth century New Spain, see Louise Burkhart, "The Solar Christ in Nahuatl Doctrinal Texts of Early Colonial Mexico," Ethnohistory 35:3 (1988), pp. 234-256.

28. E. A. Foster, Motolinia's History of the Indians of New Spain (Berkeley: The Cortés Society, 1950), pp. 8, 52. On the use of festivals, music, and dance for evangelization purposes in Spanish and Portuguese America, see Beth K. Aracena, "Singing Salvation: Jesuit Musics in Colonial Chile, 1600-1767" (Ph.D. dissertation, University of Chicago, 1999 ); Leonardo Waisman, "Viva María!" La música para la virgen en las misioncs de Chiquitos," Latin American Music Review 13:2 (Autumn-Winter 1992), pp. 213-225; Bernardo Illari, "Presencia guaraní en la música de las misiones," Revista de musicológica 16:4 (1993), pp. 2126-2132; Paulo Castagna, "The Use of Music by the Jesuits in the Conversion of the Indians of Brazil," in The Jesuits: Caltures, Sciences and the Arts, 1540-1773, ed. John W. O'Mallcy, S.J., Gauvin Alexander Bailey, Steven J. Harris, and T. Frank Kennedy, S.J. (Toronto: University of Toronto Press, 2000), pp. 641-657; and William J. Summers, "The Jesuits in Manila, 1581-1621: The Role of Music in Rite, Ritual, and Spectacle," in the same volume, pp. 659-679.

29. See Bernardino de Sahagún, Florentine Codex: Book 2, the Ceremonies, trans. Arthur J. O. Anderson and Charles E. Dibble (Salt Lake City: University of Utah Press, 1981), Elizabeth H. Boone, "Incarnations of the Aztec Supernatural: the Image of Huitzilopochtli in Mexico and Europe," Transactions of the American Philosopbical Society, new series, 79:2 (1989), pp. 4-7, 34-37.

30. Carlos Jáuregui, "Saturnal cannibal: fronteras, reflejos, y paradojas en la narrativa sobre el antropófago," Revista de critica literaria latinoamericana 26:51 (2000), pp. 26-27. 
ing period preceding Panquetzaliztli was easily equated with Advent, a contemplative period. Songs, dances, and processions of the Holy Family, which ended at the church on Christmas Day, a day of feasting and dancing, also fit into preexisting devotional patterns. Consumption of Huitzilopochtli's image in the temple translated to the consumption of the body and blood of Christ during the Eucharist on Christmas Day.

By the end of the sixteenth century, missionaries had successfully integrated Christmas into the yearly cycle of festivals in central New Spain. The birth of Jesus and the image of the Virgin Mary as a loving mother were celebrated in art, dance, and song, many created or performed by indigenous artisans. ${ }^{31}$ For example, the Nahuatl song texts of the cantares mexicanos contain lyrics, penned by indigenous authors, which elaborate on the biblical themes of Jesus and Mary at Christmas. These songs were meant to be accompanied by native drums. ${ }^{32}$ Public concerts of these songs fit into the tradition of Nahua public performances, in which the act of singing was understood as a sacrificial act that connected the singer or musician with the cosmos in order to influence the world. ${ }^{33}$ Even public performance of songs with Christian themes could reinforce native cultural identities. Polyphonic songs with Nahuatl lyrics dedicated to the Virgin Mary appeared in the Códice Valdes of 1599, and Juan Gutiérrez de Padilla and Gaspar Fernandes wrote Christmas-themed villancicos in the early seventeenth century, some of which incorporated indigenous language and rhythms. ${ }^{34}$ Not only the Christmas songs, but also the performances and contexts of such ceremonies, contained layers of meaning and cultural borrowing.

In rural areas of New Spain, the cycle of Catholic festivals regulated many aspects of public life as well as social and individual life in mission communities. Food was stored for feasting at celebrations, musicians rehearsed and sometimes traveled to partake in festivities, and gifts were distributed. As the Jesuits and Franciscans

31. On Marian images produced by indigenous artists, sce Jeanette Favrot Peterson, "Creating the Virgin of Guadalupe: The Cloth, the Artist, and Sources in Sixteenth Century New Spain," The Americas 61:4 (2005), pp. 573574,583 .

32. On the cantares mexicanos, see John Bierhorst, ed. and trans. A Nahuatl-English Dictionary and Concordance to the Cantares Mexicanos (Stanford: Stanford University Press, 1985), p. 95, Frances Kartunnen and James Lockhart, "La estructura de la poesía náhuatl vista por sus variants," Estudios de Cultura Nábuatl XIV (1980), pp. 15-64, Gary Tomlinson, The Singing of the New World: Indigenous Voice in the Era of European Contact (Cambridge: Cambridge University Press, 2007), p. 60.

33. Sec the work of Miguel Léon-Portilla, including Native Mesoamerican Spiritzality. (New York: Paulist Press, 1980), pp. 38-40.

34. For Franco, see Eloy Cruz, “De como una letra hace la diferencia: las obras en Náhuatl atribuidas a Don Hernando Franco," Estudios Cultura Nábuatl 32 (2001), pp. 257-29.1; for the villancicos of Padilla and Fernandez see Robert Murrell Stevenson, Christmas Music from Baroque Mexico (Berkeley: Universiry of California Press, 1974). Musjcologist Drew Davies has argued that elements in seventeenth-century villancicos were actually inagined representations of ethnic music and dance, particularly in the subgenre of villancico termed negrillo. "The Italianized Frontier: Music at Durango Cathedral, Español Culture, and the Aesthetics of Devotion in Eighteenth-Century New Spain," Ph.D. Dissertation: University of Chicago, 2006. 
moved into the northern frontier of New Spain, beginning in the late sixteenth century, music was interwoven into the reorganization of ceremonial time in the new mission communities. Specific elements of the liturgy, as well as extra-liturgical dances, dramas, and devotional songs, were performed for different feast days, especially the important celebrations of Christmas, Holy Week, and Corpus Christi. Members of the community were encouraged to process from their homes to the church patio to the beat of indigenous percussion instruments and the sound of Christian responsories.

\section{Christmas in Seventeenth-Century NORTHERN JESUIT MISSIONS}

Jesuit missionaries traveled north into Durango, Sinaloa, and Nueva Vizcaya in the last decades of the sixteenth century. Building on their educational foundations in central New Spain, Jesuits educated and raised young boys at the Colegio de San Felipe de Sinaloa. Students in the colegio learned to read, write, sing, and play instruments. Missionary accounts described them as exemplary musicians who performed for Spanish settlers on first-class feasts, including Christmas. ${ }^{35}$ Feast days furnished opportunities to display Christianity and doctrine to even those who had not been congregated in the missions. Spanish settlers, soldiers, and Christianized Indians from central Mexico joined neophytes in both liturgical and extra-liturgical activities - evening Vespers on Christmas Eve, Mass in the very early morning hours of Christmas (Misa de Gallos), and dancing for the remainder of the day.

Jesuit missionary Andrés Pérez de Ribas emphasized the importance of the celebration of Christian festivals when he wrote about the 1605 dedication of a new church building at Mochicahui, among the Zuaque, to which neighboring nations were invited:

They could see that with Christ's law they were not being stripped of festivals and honorable and holy celebrations, which replaced their former profane and atrocious ones. Care was taken to solemnize this celebration through all possible means of joyful and pleasing spectacle, for the spiritual conquest of the Zuaque constituted the most difficult-to-defeat fortress of the many that the devil possessed in this province. Therefore, nothing was spared in terms of music, dances, and fires that could be had in such a poor land. ${ }^{36}$

35. Cartas anuas de $1611,1612,1613$, cited in Francisco Zambrano, Diccionario bio-bibliográfica de la Companía de Jeszis en México, vol. 4 (México: Editorial Tradición, 1977), pp. 417, 431, 453, and Mariano Cuevas, Historia de la igelsia en Mexico, 4 volumes (El Paso: Editorial Revista Católica, 1928), p. 336.

36. Andrés Pérez de Ribas, History of the Triumphs of Our Holy Faith, trans. Daniel T. Reff, Maureen Ahern, and Richard K. Danford. (Tucson: University of Arizona Press, 1999), book 3, chapter 12, p. 225. For a discussion of this event, see Marco Antonio Borboa Trasviña, "La conquista de la Provincia de Sinaloa y la evangelización de los indios Zuaques de Mochicahui," Ra Ximhai 3:2 (May-August 2007), pp. 338-340. 
Large numbers of Indians came for bonfires, dances, drums, and song on the evening before the dedication of the church and a Marian shrine. A great feast followed Vespers, which included music played by Indian converts on chirimias and trumpets. The piety and devotion of this account present a strong contrast with the persistent aggressive resistance against Spanish military and religious occupation by the Zuaques, Tehuecos, and Sinaloas of the region, both through physical force and the opposition of shamans. Pérez de Ribas's description of early Jesuit work in Sinaloa, with its vivid descriptions of both martyrdom and mass conversions, was intended to inform, as well as teach, potential recruits about missionary work in northern New Spain. In this example of a caso de edificación, he triumphantly explained how celebrations for special religious occasions, particularly those involving familiar practices of nocturnal indigenous dances and feasting, could win converts. Open defiance and cultural accommodation operated simultaneously in the northern Jesuit frontier, and both could exist in the arena of performances for special occasions. ${ }^{37}$

In the Jesuit missions of northern New Spain, indigenous singers, and even melodies merged with the concepts of Catholic doctrine to create European-style religious music - spiritual songs, prayers such as the rosary and Our Father, and antiphons such as the Salve Regina-affected by cultural borrowing. The performances of this religious music, in contexts far removed from the cathedrals and parish churches of Europe, were endowed with layers of meaning for performers and the entire audience. A Christmas celebration in 1598 at the mission of Parras in Nueva Vizcaya (today Coahuila) began with the ceremonies inside the church to honor Mary and the Christ Child. Afterwards, the celebration flooded into the plaza in front of the church, where Laguneros and neighboring groups gathered to sing and dance:

adorned with feathers of various colors from guacamayos and other birds. They held arrows in their hands, as was their custom, and sang words that were no longer barbarian but rather Christian. . . The songs of our Indians, translated from their language, in which they sang, went as follows: 'God our Lord is worthy of praise; the feast of Our Lady makes us happy; let men praise Our Lady and mother; let us worship the place where Our Lady is found, she who is the Mother of God and Our Lord.' These motets were repeated and sung in the tone and rhythm that they use. ${ }^{38}$

37. See Maureen Ahern, "Martyrs and Idols: Performing Ritual Warfare on Early Missionary Frontiers in the Northwest," in Religion in New Spain, ed. Susan Schroeder and Stafford Poole (Albuquerque: University of New Mexico Press, 2007), p. 292, and Cynthia Radding, "Cultural Boundaries between Adaptation and Defiance: The Mission Com. munities of Northwestern New Spain," in Nicholas Griffiths and Fernando Cervantes, eds., Spiritual Encounters: Interactions between Christianity and Native Religions in Colonial America (Lincoln: University of Nebraska Press, 1999), pp. 116-118.

38. Pérez de Ribas, History of the Triumphs of Our Holy Faith, book 11, chapter 10, pp. 669-670. 
At Parras, indigenous language, vocal timbre, dances, arrows, and dress were combined with Hispanic Christian themes. Newly created lyrics emphasized the Virgin Mary as the mother of Christ, a particular focus of Jesuit devotion, and an important role model for introducing European, Catholic ideals of motherhood to indigenous women. While the content of the songs was Christianized, the language, rhythm, tone, and performance context retained Indian characteristics. Dances were held in the plaza in front of the church, around bonfires at night and involved over 100 participants. As we have seen, dances were not uncommon in folk European Christmas celebrations, but they were not as large, nor as long in duration. Laguneros and other indigenous groups of the Bolsón de Mapimí performed large communal dances for war, and as celebrations for happiness or to express sadness. They lasted for long periods, sometimes days, around large bonfires in circles in which both men and women participated. ${ }^{39}$ In the Christmas dances held during this early missionization effort at Parras, the indigenous character of the dances was impossible to ignore. For the Laguneros and neighboring groups who gathered at Parras, performing such dances, even with altered words, communicated and reinforced group identity. Christian celebrations at the mission provided a space and occasion for naciones of the region to gather, perform dances, and partake of the roasted heifers and maize dishes served the following day. ${ }^{40}$ For Pérez de Ribas and other Jesuit missionaries of the north, allowing the dances was a way of inviting Laguneros to participate in Christian rituals and messages, and eventually, into a sedentary, Christian life at the mission. Father Juan Agustín Espinosa noted that baptisms and marriages were performed on Epiphany following this large fiesta. Both Jesuits and Laguneros gained material benefits by participating in syncretic ritual performances.

To the northwest, Jesuits worked among populations of semi-sedentary Tarahumaras, Tobosos, Conchos, and Tepehuanes in Nueva Vizcaya. Like in central New Spain, missionaries targeted children, particularly boys, for instruction. They encouraged collaboration by rewarding those who followed the examples of Hispanicized converts with tools and other gifts. Some children quickly learned Spanish, Latin, and could sing Christian songs and recite the prayers. ${ }^{41}$ Others were instructed in plainchant or learned to play chirimías, bajones, or stringed instruments. ${ }^{42}$ Groups of specialized performers were particularly valued for their musi-

39. William B. Griffen, Culture Change and Shifting Population in Northern Mexico (Tucson: University of Arizona Press, 1969), p. 123.

40. Pérez de Ribas, ibid., and Francisco Zambrano, Diccionario bio-bibliográfica de la Companía de Jesús en México, vol. 6 (México: Editorial Tradición, 1977), pp. 480-481.

41. The Jesuit annual letter from 1615 stated that children at a visita of San Ignacio del Zape learned to chant the Mass by memory in only one year. 1615 ARSI, prov. Mex. vol. 15, fol. 26v, Vatican Film Library, St. Louis University, roll 140 .

42. For cxample, Ortiz Zapata's report from 1678 lists instruments such as clarins, chirimías, bajoncs, harps, and guitars at Santa Cruz de Topia, San Lorenzo de Guepaca, San Francisco Xavier Arevechi, Nuestra Señora de la 
cal talents. In order to learn specialized music, both vocal and instrumental, they spent hours practicing instead of adhering to the agricultural or pastoral duties typical of many residents of mission communities. Choirs and groups of musicians traveled to nearby mission pueblos to perform for special occasions such as Christmas and titular feast days. Larger groups could participate in pastorelas, which reenacted the visit of shepherds to the Holy Family. At the Christmas celebration at Santiago Papasquiaro in 1611, Tarascans and Mexicanos dressed as shepherds and traveled to a manger in the church, where they offered gifts to the infant Jesus, recreating the veneration of the Christ Child. Converted and Hispanicized Indians modeled great devotion and affection for the Christ Child in the presence of the Tepehuanes for whom the mission was built. During Lent of the same year, these converts taught the newly congregated population the processions and rituals of Holy Week. ${ }^{43}$ Throughout the Sierra Tarahumara in the early seventeenth century, rancherias and Spanish vecinos came to the church and reportedly participated in worship in both Tarahumara and Spanish. ${ }^{44}$ Feast days were instrumental to the formation of group and Catholic identity, for even those who did not live in the missions attended the pageantry surrounding the performance of pastorelas at Christmas and the procession of the host on Corpus Christi. ${ }^{45}$

Despite the outward adoption of the Christian calendar of feasts and Hispanic customs, unrest in the northern Jesuit missions often disrupted evangelization efforts. The Tepehuan Revolt of 1616 occurred after a generation of congregation in the Jesuit missions of Santiago Papasquiaro, Santa Catalina, San Ignacio del Zape, and San Miguel de las Bocas. Led by a shaman named Quautlatas, who urged Tepehuanes to stop participating in Christian rituals, for those who failed to revolt would be punished by plague, famine, and earthquake, this revolt aimed to remake a world void of Spanish presence. ${ }^{46}$ By 1619, the Spanish had mostly restored their authority in the region, through both military and material means. Throughout the seventeenth century, many indigenous peoples of the north gradually adopted tools, weapons, and animals brought by the Spaniards, and incorporated the Catholic ritual calendar into their own yearly cycles. After the Tepehuan Revolt, and other first-generation rebellions throughout the northern Jesuit missions, gift-

Concepción Movas, San José de Mátape, San Miguel de Oposura, Bavispe, Asunción Arispe, Nuestra Señora de los Angeles de Sahuaripa, San Andrés Conicari, San Francisco Xavier Batuco, and groups of singers at several of these missions. See AGN Misiones, leg. 26, transcribed in Documentos para la historia de mexico, scrie 4, vol III.

43. Carta anua de 1611, in González R, ibid., pp. 165-166.

44. José Pascual to Padre Provincial, 1651. AGN Historia vol. 19, fol. 203v-204v.

45. Cartas anuas de 1608, 1611 and 1613, in Luís González Rodrígucz, ed. Crónicas de la Sicrra Tarahumara (México: Secretaria de Educación Pública, 1987), pp. 148, 160-165, 174-175.

46. On the Tepehuan revolt, and the characteristics of first-generation revolts in the seventeenth century northern Jesuit missions see Deeds, Defiance and Deference in Mexico's Colonial North, pp. 30-38. See also Charlotte M. Gradie, The Tepehuan Revolt of 1616: Militarism, Evangelism, and Colonialism in the Seventeenth Century (Salt Lake City: University of Utah Press, 2000). 
giving and feasting at communal religious celebrations became significant. Large fiestas were locations at which the sights and sounds of Christian doctrine could be conveyed to large groups of people. Vespers on Christmas Eve preceded large gatherings, and masses were held on Christmas Day. ${ }^{47}$ Participants in the pastorelas and processions of the seventeenth century in Tepehuan and Tarahumara country, like their counterparts in rural medieval Spain, literally became adorers of Christ. While Jesuits hailed these demonstrations as evidence of religious conversion, we are left to wonder how indigenous peoples understood them.

As in central New Spain, Indians were able to affect the type of religious music performed in their mission communities to a limited extent. Extra-liturgical folk dance became an important part of Jesuit mission repertoires for Christmas, Corpus Christi, and titular feast days of the communities. The Jesuits in northern New Spain learned that performances of song and dance were symbolic texts that communicated multiple meanings to their indigenous performers and observers, and they accepted the ambiguity of the spiritual meanings in order to further bind Indians to Christian rituals. Although in most cases, the dances were not allowed inside the church, many of the dances retained strong indigenous components. Jesuit reports indicated that although Tepehuanes and Tarahumaras continued dancing for their own special occasions (harvest or war, for example), often at night, in a location hidden or far from missionary control, they also enthusiastically participated in celebrations of Christian feast days. ${ }^{48}$

\section{Christmas in Northern Franciscan Missions}

In Nuevo Mexico, like in Europe and central New Spain, Franciscans capitalized on the association of Christmas with the winter solstice, an important ceremonial time in the ritual calendars of the Puebloans. Although most European liturgical and folk traditions associated with Christmas did not begin until Christmas Eve, in Nuevo México, Advent took on additional importance because it coincided with the preparatory days observed by Puebloans before the winter solstice. Fasting and ritual cleansing fit into the Christian practices associated with preparing for Christ's arrival. Specific animal dances performed by clans and societies were part of the indigenous celebration of the solstice. ${ }^{49}$ Friars had little success in abolishing indigenous dances and instead tried to rededicate them to Christian figures, such as Mary, Jesus, or a pueblo's patron saint, on feast days, including Christmas. Some may also

47. Bernabe Francisco de Gutiérrez to P.P. Francisco Ximenez, 1676, AGN Misiones vol. 26, f. 220.

48. See, for example, carta anua 1608, in Luís González Rodríguez, ed. Crónicas de la Sierra Tarahumara (México: Secretaria de Educación Pública, 1987), pp. 161-162.

49. Late nineteenth-century and early twentieth-century ethnographies such as J. Walter Fewkes, "The Winter Solstice Ceremony at Walpi," American Antbropologist 11:4 (April 1898), pp. 101-115, and Erna Fergusson, Dancing Gods: Indian Ceremonials of Arizona and New Mexico (1931), detail some of these dances. 
have tried to incorporate Puebloan dances into European dance-dramas such as the matachines and Moros $y$ Cristianos dances, although the origin of these dances in Nuevo México is unclear. ${ }^{50}$ Pantomimed dance-dramas, such as the matachines, which reenacted the triumph of Christianity over evil, were an important method of communicating Christian concepts in a region in which native inhabitants steadfastly refused to use Spanish, and few Franciscans understood indigenous languages well enough to hear confessions or explain the basics of Catholic doctrine. ${ }^{51}$

Not only Franciscans, but also Puebloans refashioned and reinvented rituals, including song and dance, to keep their culture and clan identities alive. ${ }^{52}$ The performances of these rituals functioned as safety valves in which Indians could participate in revelry and articulate cultural identity without uprooting the fragile Spanish hold on frontier territory after the Pueblo rebellion of 1680 . Shortly after the reconquest of the territory, Christmas at San Ildefonso was celebrated with sung Matins on Christmas Eve, a vigil, and a special mass with singers on Christmas Day. Throughout the day, dances were held in the pueblo in conjunction with the Christian rituals. ${ }^{53}$ Thus, the colonization of ceremonial time in the form of the imposition of a Catholic ritual calendar did allow some space for indigenous actors to affirm and reshape their own cultures. Christian festivals held by the church could also open the door for indigenous cultural practices, which were incompatible with efforts to impose ideological and behavioral standards. Missionary-sponsored festivals had dimensions that escaped missionary control. The practice of trying to colonize ritual time through the establishment of new ritual calendars could open a space for indigenous peoples to practice or even re-invent their own cultural practices in public and with a wider audience, including Spanish and mestizo settlers and soldiers who frequented mission communities on feast days. ${ }^{54}$

50. There have been many excellent works on the matachines dances of New Mexico. For example, see Flavia Waters Champe, The Matachines Dance of the Upper Rio Grande: History, Music, and Choreography (Lincoln: University of Nebraska Press, 1983); Sylvia Rodríguez, The Matachines Dance: Ritusal, Symbolism, and Interethnic Relations in the Upper Rio Grande Valley (Albuquerque: University of New Mexico Press, 1996); Brenda Rae Romero, "The Matachines Music and Dance in San Juan Pueblo and Alcalde, New Mexico: Context and Meanings," D. M. A. dissertation, University of California at Los Angeles, 1993. These dances were not limited to New Mexico, although they were particularly associated with preparation for Christmas in eighteenth century New Mexico. On matachines dances in northern Mexico, see Jesus Jáuregui and Carlo Bonfiglioli, Las danzas de conquista (México: Fondo de Cultura Económica, 1996); and Carlo Bonfiglioli, Fariseos y matachines en la Sierra Tarabumara (México: Instituto Nacional Indigenista, 1995). See Ramón Gutiérrez, When Jesus Came, the Corn Mothers Went Away: Marriage, Sexuality and Power in New Mexico, 15001846 (Stanford: Stanford University Press, 1991), p. 84.

51. Bishop Crespo's report from 1730, reprinted in Eleanor Adams, ed., Bishop Tamarón's Visitation of New Mexico, 1760 (Albuquerque: University of New Mexico Press, 1954), pp. 102-103, expressed contemptuous criticism towards Franciscans for their failure to learn native languages. Bishop Tamarón's visita report from 1760, and Fray Atanasio Domínguez's report from 1776 consistently mention the failure of Franciscans, even those who served in an area for an extensive period of time, to learn native languages.

52. On music's role in identity formation, see Christopher Small, Musicking: The Meanings of Performing and Lis* tening (Hanover: University Press of New England, 1998), pp. 97-98.

53. Francisco Corbera to Father Guardian, 12/27/1694, in Espinosa, ed., pp. 123-124.

54. Bishop Francisco Atanasio Domínguez, visita report, San Lorenzo de Picuris, 1776, in Adams, ed. The Missions of New Mexico, p. 95. 
Beginning in the late eighteenth century, Franciscans established missions and congregated indigenous groups along the coast of Alta California. As elsewhere in the Spanish empire, ritual and music were central to the missionaries' plans for acculturation and conversion. A number of the Franciscan members of the apostolic college of San Fernando in Mexico City who served in Alta California were accomplished musicians and even composers. Their talents led to sophisticated choral and instrumental compositions and performances as part of celebrations for feast days. ${ }^{55}$ Nineteenth-century Franciscan Florencio Ibáñez, missionary at San Antonio de Padua (1801-1803) and Soledad (1803-1818) likely produced a pastorela performed in the Alta California missions. ${ }^{56}$ Father Magín Catalá at Santa Clara staged a pastorela, perhaps that written by Ibáñez, for the Indian children at the mission. More than a pantomimed recreation of the shepherds' visitation by the angels and adoration of the infant Jesus, it contained music performed by soloists, the mission choir and orchestra and the pealing of mission bells. ${ }^{57}$ Pastorela scripts, such as these, at approximately 30 pages with music in the vernacular Spanish, were "feats of memory and imagination" in which adaptation and improvisation were common. ${ }^{58}$ Their performance involved hours of preparation and significant numbers of mission residents who invited their fellow congregants, brother shepherds, to come and worship the infant Jesus. ${ }^{59}$

Christmas entered mission communities year-round, not only in December, through sights and sounds. From their order's foundation, Franciscans showed special devotion to the images of Christ in the nativity and the passion. Sermons, paintings, and lyrics of spiritual songs indicated this devotion. An alabado, or song of praise, written by Fray Antonio Margil de Jesús and sung all through the Texas missions he administered, centered around the refrain, Amen, Jesus y Maria, Jesus, Maria y José. ${ }^{60}$ Mission residents in many northern communities sang the

55. On the musical abilities of the californios, see Maynard Geiger and Clement Meighan, As the Padres Saw Them: California Indian Life and Customs as Reported by the Franciscan Missionaries, 1813-1815 (Santa Barbara: Santa Barbara Mission Library, 1976), esp. pp. 36-37, 133-136. On the extensive music of the California missions, see Margaret Crouch, "An Annotated Bibliography and Commentary Concerning Mission Music of Alta California from 1769 to 1834: In Honor of the American Bicentennial," Current Musicology 22 (1976), pp. 88-99 and William J. Summers, "Spanish Music in California, 1769-1840, a Reassessment," in Report of the Twelfth Congress of the International Musicological Society, Berkeley, 1977. Daniel Heartz and Bonnie Wade, eds. (Kassel: Barenreiter-Verlag, 1981), pp. 360-380.

56. William J. Summers, “Sancho: Alta California's Preeminent Musician” in Juan Bautista Sancho: Pioneer Composer of California (Palma, Mallorca: Universitat de les Illes Balears, 2007), pp. 69, 76-77.

57. Halpin, p. 39

58. Margaret Cayward, "A Pastorela from 18th-century Alta California," paper presented at Encuentros/Encounters 2009: Mission Music of California, January 30, 2009, University of California, Riverside.

59. Cayward identified four pastorela scripts which seem to come from a common source: two from the De la Gucrra Collection at the Santa Barbara Mission Archive Library, Quaderno de Lizardo, BANC MSS 68/115c, in the Pio Pico papers at the Bancroft Library, and fragments of a script in the Domingo Carillo papers, BANC MSS C-B 72 . A pastorela song from the Santa Barbara Mission Archive Library, identified by Cayward, concludes, "Let's go, brother shepherds, to worship the redeemer."

60. Fray Isidro Felix de Espinosa, Crónica de los Colegios de Propaganda Fide de la Nueva España, Lino Gomez Canedo, ed. (Washington, D.C.: Academy of American Franciscan History, 1964), pp. 594-595. The alabado contains one verse each devoted to Mary and Joseph. 
alabado several times during the day, with verses alternating between men and women, further emphasizing gender divisions, parenthood, the centrality of a nuclear family, and the importance of the Holy Family of the nativity. ${ }^{61}$ Friars attempted to inculcate this sort of devotion in the mission communities where they worked. The image of Christ as a child, surrounded by his mother and father, emphasized the model Christian family-humble, devoted, and pious. ${ }^{62}$ Although the indigenous peoples of the north understood familial relationships and lived in extended kin groups, the concept of a nuclear family unit, with mother, father, and children, was not part of most native practice. There is evidence that the populations of Franciscan missions in northern New Spain adopted veneration of the infant Jesus and his parents, but Mary, as the female face of god, was more widely accepted than the veneration of the Holy Family. At Santa Cruz de la Cañada in Nuevo México, a mixed-race population adorned their church with statues of Mary and the Christ Child. Two women in the pueblo provided ornaments and special cloths to adorn the statue of Mary. Friars oversaw the distribution of bundles of firewood and candles for the feast day of Nuestra Señora de la Concepción, while a special mass was performed in honor of St. Joseph on the nineteenth day of each month, at which many took communion..$^{63}$ Similarly, on the feast day of the Immaculate Conception at Mission Concepción in San Antonio, missionaries provided candles to Indian women so that they could physically bring the light of Christ into their homes. The community prayed the rosary together, and the worship service ended with all singing the Salve Regina. ${ }^{64}$ Children at Mission Espíritu Santo de Moris learned songs composed by their friar, Padre Vicente Escalera, to sing in honor of the infant Jesus, and others which honored Mary and Joseph. ${ }^{65}$ Reminders of the Holy Family were scattered throughout the year, in song and visual art, and they culminated in the preparatory period of Advent,

61. See, for example, Howard Benoist and Eva Maria Flores, eds. Documents Relating to the Old Spanish Missions of Texas: Volume I: Guidelines for a Texas Mission: Instructions for the Missionary of Mission Concepcion in San Antonio (San Antonio: Old Spanish Missions Historical Research Center) (1787), 5; and Antonio de los Reyes to the king, AGI Guadalajara 586, 2 sept 1774. f/ 39v-40. On the importance of the alabado in restructuring daily schedules, see Kristin Dutcher Mann, The Power of Song Missions of Northern New Spain, (Ph.D. dissertation, Northern Arizona University, 2002), chapter 4 .

62. On religious artwork in New Spain, see Clara Bargellini, "Stars in the Sea of the Church: the Indian in Eighteenth-Century New Spanish Painting," The Arts in Latin America, 1492-1820, cd. Joseph J. Rishel and Suzanne Stratton (New Haven: Yale University Press, 2006), and Gauvin Bailey, Art on the Jestit Missions in Asia and Latin America, 1542-1773 (Toronto: University of Toronto Press, 1999). On the use of artwork to convey doctrine in Alta California, and its reception among indigenous converts, see Steven Hackel, Children of Coyote, pp. 148-152. See also Robert H. Jackson, "Visual Representations of Religious Conversion in Spanish American Missions," Boletin 25:2 (2008), pp. 5-30 and Susan Anderson Kerry, "Preliminary Observations on Angels in Religious Art in New Spain," Boltetín 25:2 (2008), pp. 31-48.

63. Bishop Francisco Atanasio Domínguez, visita report, Santa Cruz de la Cañada, 1776, in Adams, ed. The Missions of New Mexico, pp. 75-76, 79.

64. Howard Benoist and Eva Maria Flores, eds. Documents Relating To The Old Spanish Missions Of Texas: Volume I: Guidelines For A Texas Mission: Instructions For The Missionary Of Mission Concepcion In San Antonio (San Antonio: Old Spanish Missions Historical Research Center), p. 7.

65. Biography of Padre Vicente Escalera, n.d., Old Spanish Missions Historical Research Collection, Our Lady of the Lake University, San Antonio, Texas (OSMHRC) Archivo del Colegio de Zacatecas reel 16, fr. 1421-1423. 
when no meat was consumed, and in dances, worship, and feasts on Christmas Eve and Christmas Day.

Like in other mission communities of the north, mission bells called Indians, presidial soldiers, and vecinos to worship with their families in San Antonio, Texas, on Christmas, a first-class feast day. ${ }^{66}$ The community gathered together at Mission San Juan Capistrano for matachines dances held to celebrate the nativity of Christ, some of which included indigenous ankle-rattles, cascabels, and masks. ${ }^{67}$ Franciscans in San Antonio believed that indigenous mitotes should be permitted, provided that Indians had no "sinful motives." ${ }^{68}$ The small bands of Indians gathered at these missions were then able to continue passing on their traditions of dance, even to young children, by reshaping their culture to meet the demands of the colonial situation. Instead of having to perform their dances in secret, they integrated them into the festivities surrounding the mission's celebration of the birth of Christ. However, the ritual dances of the Coahuiltecan-speakers congregated in the San Antonio missions might not have differed significantly in outward appearance from the ring dances that were associated with the oficium pastorum, or Office of the Shepherds, an important part of Christmas celebrations in fifteenth to seventeenth century Spain. ${ }^{69}$

Christmas Eve was commemorated in a similar fashion in Mission San Bernardo del Río Grande del Norte. Like in the San Antonio missions, the Franciscan at San Bernardo served several rancherías of semi-sedentary ethnic groups in a central location and attempted to foster community religious identity through group worship on feast days. Ocanas, Pacuaches, and Pachales participated together in sung Vespers and a procession on Christmas Eve. ${ }^{70}$ Their dances may have been performed separately by ethnic groups, or over time, communally, creating a pan-Indian identity in this part of the northern borderlands. The Christmas Eve fiestas opened up a space for indigenous expression of cultural identity and allowed a more public and widespread display of indigenous culture, now combined like in other areas of northern New Spain, with the Christian liturgical calendar. The food provided for Christmas Eve revelers at Mission Concepción revealed further evidence of cultural borrowing: favorites of the Pajalates, such as camotes (a type of sweet potatoes), and beans were prepared, as well as Spanish-introduced wine, buñuelos, and other sweets. ${ }^{71}$ Indigenous musical traditions, such as the use of percussion and the con-

66. Benoist and Flores, eds., Instructions for the Missionary, p. 3.

67. 1772 inventory, Mission San Juan Capistrano, San Antonio, OSMHRC Archivo del Colegio de Querétaro reel 10 , fr. $4271-4294$.

68. Benoist and Flores, eds., Instructions for the Missionary, pp. 35, 37.

69. See Stern, "Fray Iñigo de Mendoza and Medieval Dramatic Ritual," p. 233.

70. Fray Isidro Felix de Espinosa, Crónica de los Colegios de Propaganda Fide de la Nueva España, Lino Gomez Canedo, ed. (Washington, D.C.: Academy of American Franciscan History, 1964), p. 755.

71. Benoist and Flores, eds., Instructions for the Missionary, pp. 17, 35. Elsewhere in this document, the missionary warns that Indian women will try to leave the mission to gather nuts, berries, and fruits of cactus, along with camotes 
nection of dance with ritual, were combined with European traditions associated with the mass and divine office, and reincorporated into the devotional practices of both Indians and missionaries. The persistence of indigenous dances, as well as Spanish-influenced matachines in the pueblos of Nuevo México as well as among Yaquis and Tarahumaras in the greater borderlands region is evidence of the adaptation of indigenous cultures, and of the missionaries who worked among them. The elaborate Catholic ceremonies that mission Indian leaders organized and performed in their new communities served the purpose of substantiating their status as new Christians in the eyes of the Spaniards. This allowed communities some protection against exploitation and land encroachment while also symbolizing the existence of a new community generated through cultural recreation. ${ }^{72}$

\section{Conclusions}

The study of Christmas celebrations in northern borderlands missions yields two important conclusions. First, second only to Holy Week and Easter, Christmas was the most important feast of the year in most northern communities. ${ }^{73}$ This may be attributed to the centrality of dance in Christmas celebrations-a feature that resonated with Spanish missionaries and settlers, but particularly with indigenous groups. ${ }^{74}$ Amongst both groups, and in the hybrid mission communities, dances constructed a whole community out of smaller components, demonstrated beliefs

(43). He also advises that they will continually ask for sweets from the missionary (17). By controlling the time at which these items were distributed or available to the wider community, Franciscans could ensure broad participation in celebrations for feast days, and quickly encourage Indians to adopt the Christian calendar.

72. For a similar response among Tarahumara in the eighteenth century, sec William Merrill, "Conversion and Colonialism in Northern Mexico: The Tarahumara Response to the Jesuit Mission Program, 1601-1767," in Conversion to Christianity: Historical and Antbropological Perspectives on a Great Transformation (Berkeley: University of California Press, 1993), p. 151.

73. Geoffrey Baker found that Christmas was the most important musical event of the year in the convents and monasteries of colonial Cuzco, Imposing Harmony: Music and Society in Colonial Cuzco (Durham: Duke University Press, 2008), p. 16. In metropolitan areas of New Spain, Corpus Christi seems to have had particular importance. On celebrations for Corpus Christi in the Spanish empire, see Carolyn Dean, Inka Bodies and the Body of Christ: Corpus Christi in Colonial Cuzco, Peru (Durham, N.C.: Duke University Press, 1999), David P. Cahill, "Popular Religion and Appropriation: The Example of Corpus Christi in Eighteenth-Century Cuzco," Latin American Research Review 31:2 (1996), pp. 67-110, and Linda Curcio-Nagy, "Giants and Gypsies: Corpus Christi in Colonial Mexico City" in Rituals of Rule, Rituals of Resistance: Public Celebrations and Popular Culture in Colonial Mexico (Boston: Rowman \& Littlefield, 1994), pp. 1-26. For Corpus Christi in northern missions, see Kristin Dutcher Mann, "The Power of Song in the Missions of Northern New Spain," (Ph.D. dissertation, Northern Arizona University, 2002), chapter 5.

74. There are numerous references to dances as part of Christmas in northern missions throughout the colonial period. For Nucva Vizcaya, see Diccionario Bio-Bibliográfica vol. 6, pp. 148-149 (1598); for Baja California, sec Fray Manuel de la Vega, Relacion de la descubrimiento y conquista de las Californias, Biblitoeca Nacional de Antropología e Historia, Fondo Franciscano (BNAH/FF) vol. 68, f. 24v (1699) and Constantin Bayle, Misión de la Baja California, p. 101. For the Pimería Alta (1704), Herbert Eugene Bolton, Kino's Diary of the Anza Expedition, pp. 110-111. For New Mexico, (1694) Espinosa, Cronica Apostolica y seraphica de todos los colegios de propaganda fide de esta mueva españa, Mexico, Lino Gómiz Canedo, ed, pp. 123-124. For Texas (1767) Gaspar José Solis diary, OSMHRC Archivo del Colegio de Querétaro reel 10, fr. 4271-4294. 
and power hierarchies, and created enclosed spaces with clearly defined boundaries. ${ }^{75}$ Missionaries tried to demonstrate their authority and reinforce Christian doctrine by repurposing indigenous dances-changing the characters, providing additional costumes, such as scarves, shoes, and shirts, and by adding European musical instruments such as the violin and guitar. On the other hand, Indians asserted their control by selecting performers and musicians, as well as those allowed within the boundaries of the circular dances. Indigenous percussion instruments or bodily movements dictated the tempo and rhythm of performances. As the primary participants in these dances, Indians, and later mestizos, found their own meanings in the dances. ${ }^{76}$

Secondly, reports of Christmas celebrations by missionaries in northern New Spain reveal the localization of cultural accommodation and exchange. While important similarities, such as the centrality of dance, and the liturgy of Christmas Eve Vespers and Mass on Christmas Day, were present in these descriptions, differences related to the characteristics of individual communities are also striking. In northern missions, both Jesuit and Franciscan, pastorelas-religious dramas re-enacting and elaborating upon the nativity narrative reported in Luke 2:1-20-were performed, successfully drawing crowds to the missions. These plays, like those in Spain, involved peasant converts, some of whom were pastores like those in the Biblical narrative, in the adoration of Christ. In contrast, shepherds' plays were not specifically mentioned in missionary reports of Christmas celebrations in areas where sheep raising was not a key feature of the mission economy. In areas where nocturnal dances and bonfires were important parts of indigenous rituals, these practices also became part of Christmas fiestas. Local conditions also dictated the character of Christmas celebrations in the Jesuit missions of Baja California. In these communities, where constant food sources were scarce due to the geography of the arid peninsula, feasting and the distribution of food stores were central components of the Christmas day festivities. ${ }^{77}$ Accommodation to local cultural practices was not limited to performances of music and dance, but extended into sermons and teaching. As Cynthia Radding demonstrated, fray Antonio Barbastro's 1792 Christmas sermon to Opatas at Aconchi localized the nativity story. Mary gave birth to Jesus in a cave, a traditional sacred place for the Opata, in the traditional birthing position of a native woman. Fray Antonio helped residents of Aconchi to see their place in the adoration of Christ; he encouraged them to follow

75. On these characteristics in European Renaissance dance, see Jennifer Nevile, "Dance and the Garden: Music and Static Choreography in Renaissance Europe," Renaissance Quarterly 52:3 (Autumn 1999), p. 806.

76. Stanely L. Robe aruged this about the Los Pastores folk dramas in nineteenth and early twentieth century New Mexico in "The Relationship of 'Los Pastores' to Other Spanish-American Folk-Drama," Western Folklore 16:4 (October 1957), p. 285

77. Fray Manuel de la Vega, Relacion de la descubrimiento y conquista de las Californias, Biblioteca Nacional de Antropología c Historia, Fondo Franciscano (BNAH/FF) vol. 68, f. 12r. (1698); f. 23v (1699). 
the example of the shepherds who came to the cave repeatedly to worship the Infant Jesus with their hearts and souls. ${ }^{78}$

A study of Christmas celebrations, then, helps us to understand the cultural interaction and accommodation in northern mission communities. As larger numbers of mestizo and Hispanic settlers moved into the northern frontier, participants continued to reshape their celebrations to reflect the characteristics of the local community. Extra-liturgical folk-dramas, such as posadas and pastorelas, grew in importance in the nineteenth and twentieth century small ranching communities of New Mexico, California, and Texas. Meanwhile, strikingly different types of matachines dances, which shared strong rhythmic components, rattles, and drums, but contained varying narratives, characters, masks, costumes, and features of local Indian dances, became key features of Advent and Christmas celebrations in northern Mexico and in the New Mexican pueblos. Christmas celebrations in northern New Spain revealed the tension and accommodation present when cultural practices collided.

Joe Sando's description of Christmas at Jémez Pueblo demonstrates that modernday celebrations in the borderlands of the United States and Mexico continue to reflect the tensions between, and amalgamations of, indigenous and Hispanic cultural influences, and in the United States between Anglo-American and Hispanic culture. Posadas, pastorelas, luminarios, and midnight masses, along with family gatherings and feasting on tamales and camotes are now considered "traditional" borderlands Christmas practices, even if their origins have become lost, confused, or reinvented..$^{79}$ Ultimately, Christmas rituals of this region, both past and present, underscore the constant recreation of culture and tradition in the region and the relationship between ritual and identity.

University of Arkansas, Little Rock

Kristin DUTCher MANn

Little Rock, Arkansas

78. Barbastro, "Plática del Nacimiento de Jesuchristo, Año de 1792," in Cynthia Radding, "Crosscs, Caves, and Matachinis: Divergent Appropriations of Catholic Discourse in Northwestern New Spain," The Anericas 55:2 (October 1998), pp. 188-189.

79. Mary MacGregor-Villarreal, "Celebrating Las Posadas in Los Angeles," Western Folklore, 39:2 (April 1980), $71 \cdot 105$, and Stanlcy Brandes, "The Posadas in Tzintzuntzan: Structure and Sentiment in a Mexican Christmas Festival," The Journal of American Folklore 96:381 (Jul.-Sept. 1983), pp. 259-280. 